\title{
Identification of 14-3-3 $\zeta$ as a potential biomarker in gastric cancer by proteomics-based analysis
}

\author{
XIN-XIN LIU ${ }^{1,2}$, HUA YE $^{1}$, PENG WANG $^{1}$, YI ZHANG $^{1}$ and JIAN-YING ZHANG ${ }^{1-3}$ \\ ${ }^{1}$ Center for Tumor Biotherapy, The First Affiliated Hospital of Zhengzhou University and College \\ of Public Health, Zhengzhou University, Zhengzhou, Henan 450052, P.R. China; ${ }^{2}$ Department of \\ Biological Sciences, The University of Texas, El Paso, TX 79968, USA; ${ }^{3}$ Henan Academy of Medical \\ and Pharmaceutical Sciences, Zhengzhou University, Zhengzhou, Henan 450052, P.R. China
}

Received September 26, 2016; Accepted July 20, 2017

DOI: $10.3892 / \mathrm{mmr} .2017 .7496$

\begin{abstract}
The identification of tumor biomarkers to support early diagnosis and tumor progression monitoring may potentially reduce the mortality of gastric cancer (GC). The present study aimed to detect novel tumor-associated antigens from the AGS GC cell line, and to identify their associated autoantibodies in sera from patients with GC by proteomics-based approaches. Proteins from AGS cell lysates were isolated using two-dimensional polyacrylamide gel electrophoresis, and western blotting was subsequently performed, to determine autoantibody responses in sera derived from patients with GC and healthy individuals. Positive protein spots were removed from gels stained with Coomassie blue, and were then evaluated by liquid chromatography-tandem mass spectrometry. Sera from patients with GC produced numerous spots, one of which was identified as $14-3-3 \xi$. Autoantibody frequency to $14-3-3 \zeta$ was $17.6 \%(15 / 85)$ in patients with GC, which was significantly higher than that in healthy control individuals $(2.4 \% ; 2 / 85 ; \mathrm{P}<0.01)$. These results suggested that the autoantibody against $14-3-3 \xi$ may be a potential serological biomarker for the detection and diagnosis of GC.
\end{abstract}

\section{Introduction}

Gastric cancer (GC) is the fourth most prevalent malignancy, and is the second most common cause of cancer-associated mortality worldwide $(1,2)$. In addition, GC is one of the most common malignancies in East Asian countries (3). The leading cause of GC-associated mortality is the late detection of advanced stage GC (IIIA-IV), due to the absence of

Correspondence to: Dr Jian-Ying Zhang, Center for Tumor Biotherapy, The First Affiliated Hospital of Zhengzhou University and College of Public Health, Zhengzhou University, 1 Jianshe Road, Zhengzhou, Henan 450052, P.R. China

E-mail: jianyingzhang@hotmail.com

Key words: gastric cancer, proteomics, autoantibody, 14-3-3६, liquid chromatography-tandem mass spectrometry early diagnostic biomarkers (4). A previous study revealed that the 5-year survival rate of patients with stage IV GC is only 7-10.1\%; however, the 5-year survival rate of patients with stage IA is $78-93.3 \%(5,6)$. Early diagnosis of GC is essential for effective therapy; therefore, the detection of sensitive and specific biomarkers for GC diagnosis may significantly improve treatment and decrease mortality rates (7).

Autoimmunity refers to the production of antibodies to autologous cellular antigens and is increasingly being associated with malignancy, as autoantibodies against tumor-associated antigens (TAA) have been discovered in the sera of patients with various cancers and may be used as novel biomarkers (8). Due to the general absence of particular autoantibodies in normal conditions or non-cancer individuals, it is feasible to use autoantibodies as serum biomarkers for cancer diagnosis. In addition, autoantibodies exhibit various properties that make them attractive early cancer biomarkers (9-11). Firstly, autoantibodies may be identified in the asymptomatic stage of cancer, and may be measured as early as 5 years prior to the onset of malignancy (12). Secondly, autoantibodies against TAAs have been detected in the sera of patients with cancer. In addition, autoantibodies may be inherently persistent and stable in the sera for relatively long periods of time. Serum biomarkers may therefore be used to recognize tumorigenesis (13).

Generally, proteomics-based methods are available for recognizing protein biomarkers in the sera of patients with cancer (14). Using this approach, we previously identified novel serological biomarkers, including the anti-heat shock protein (HSP) 60 autoantibody for hepatocellular carcinoma (15), the anti-HSP70 autoantibody for esophageal squamous cell cancer (16) and the anti- $\alpha$-enolase autoantibody for liver fibrosis (17). Measurement of serum autoantibodies against TAAs may not only facilitate diagnosis of GC, but also aid the advancement of molecular targeted therapy. The present study aimed to verify novel TAAs in the AGS GC cell line and identify associated autoantibodies in patient sera with GC using a proteomics method.

\section{Materials and methods}

Clinical materials and sample preparations. All clinical samples (85 sera samples from patients with GC and 85 sera 
samples from healthy control individuals) were obtained from the sera bank at the Cancer Autoimmunity Research Laboratory at the University of Texas (UTEP; El Paso, TX, USA). The patients with GC were histologically diagnosed and confirmed in accordance with the American Joint Committee on Cancer (18). Due to regulations regarding studies on human subjects, the names of the patients were not revealed to investigators, and some clinical information concerning sera was not available. The present study was approved by the Institutional Review Board of UTEP.

Cell culture and cell extracts. The AGS GC cell line was purchased from American Type Culture Collection (Manassas, VA, USA) and was cultured in 1640-RPMI medium (Gibco; Thermo Fisher Scientific, Inc., Waltham, MA, USA) supplemented with $10 \%$ fetal bovine serum (Gibco; Thermo Fisher Scientific, Inc.), $100 \mathrm{U} / \mathrm{ml}$ penicillin and $100 \mathrm{U} / \mathrm{ml}$ streptomycin. AGS cells were allowed to reach $90 \%$ confluence in $75-\mathrm{cm}^{2}$ Falcon tissue culture flasks. Cells were rinsed once with PBS, incubated with 1640-RPMI medium containing 25\% trypsin-EDTA (Gibco; Thermo Fisher Scientific, Inc.), and finally placed into a $15 \mathrm{ml}$ centrifuge tube.

Two-dimensional gel electrophoresis (2-DE) analysis. AGS cells were lysed in rehydration buffer $(50 \mathrm{nM}$ dithiothreitil, $8 \mathrm{M}$ urea, $0.2 \%$ bio-lyte 3/10 ampholyte, 4\% 3-[(3-cholamidopropyl) dimethylammonio]-1-propanesulfonate and $0.001 \%$ bromophenol blue) purchased from Bio-Rad Laboratories, Inc. (Hercules, CA, USA), and agitated using a vortex at room temperature for $90 \mathrm{~min}$. Insoluble substances were discarded by centrifugation at $2,922 \times \mathrm{g}$ at $4^{\circ} \mathrm{C}$ for $30 \mathrm{~min}$. The resulting supernatants were harvested, and the protein concentration was determined using the Bradford assay (Bio-Rad Laboratories, Inc.). For the first dimensional gel electrophoresis assay, $150 \mu \mathrm{g}$ protein was mixed in rehydration buffer containing bromophenol blue reconstituted in proteomics-grade water, and electrophoresis was performed on a $\mathrm{pH}$ 3-10, 7-cm isoelectric focusing (IEF) strip (Bio-Rad Laboratories, Inc., Hercules, CA, USA). IEF was conducted at $50 \mathrm{~mA}$ per gel, $250 \mathrm{~V}$ for $30 \mathrm{~min}$, followed by $4,000 \mathrm{~V}$ for $1.5 \mathrm{~h}$, and $4,000 \mathrm{~V}$ for $5 \mathrm{~h}$. Strips were instantly stored at $-80^{\circ} \mathrm{C}$ until required. In the second dimensional gel electrophoresis assay, 12\% SDS-PAGE gels for strips were used. Proteins from AGS cell lysates were isolated with 2-DE and visualized by Coomassie blue (Bio-Rad Laboratories, Inc.). To determine autoantibodies against antigens from AGS, proteins were isolated by 2-DE, transferred onto NC membranes for western blotting and then probed with sera from 10 patients with GC or 10 healthy controls. The protein spots were visualized using PDQuest 2-DE analysis software version 8.0.1 (Bio-Rad Laboratories, Inc.) (19).

One-and two-dimensional western blotting. To screen the autoantibody-positive sera, AGS cells were lysed in rehydration buffer directly and then boiled for $10 \mathrm{~min}$. After the removing of the insoluble fraction by centrifuge, samples were loaded onto $12 \%$ SDS-PAGE gel, which is subsequently transferred onto nitrocellulose membrane (Bio-Rad Laboratories, Inc.) for western blotting. Following blocking with 5\% non-fat milk prepared in Tris-buffered saline (TBS), containing $0.05 \%$ Tween-20 (TBST), for $1 \mathrm{~h}$ at room temperature, the membrane was incubated with sera at a solution of 1:200. Horseradish peroxidase-conjugated goat antihuman IgG (cat. no. 31410; Invitrogen; Thermo Fisher Scientific, Inc.) was used as secondary antibody with a dilution of 1:5,000 for $1 \mathrm{~h}$ at room temperature. The positive bands were detected with an ECL kit (Thermo Fisher Scientific, Inc.). For 2D-Western blotting, the proteins on 2D gel were directly transferred onto nitrocellulose membrane and following the same protocol as described above.

In-gel digestion. Excised gel fragments were destained with $40 \mathrm{mM} \mathrm{NH}_{4} \mathrm{HCO}_{3}$ in $50 \%$ acetonitrile. Reduction was performed with $5 \mathrm{mM}$ tris-2-carboxyethylphosphine hydrochloride (Sigma-Aldrich; Merck KGaA, Darmstadt, Germany) at room temperature for $1 \mathrm{~h}$, followed by alkylation with $50 \mathrm{mM}$ iodoacetamide (Sigma-Aldrich; Merck KGaA) for $1 \mathrm{~h}$ at room temperature in the dark. The dehydrated gel slices were digested with trypsin in $10 \mathrm{mM} \mathrm{NH}_{4} \mathrm{HCO}_{3}$ for $18 \mathrm{~h}$ and peptide digests were extracted using extraction buffer, which was performed in a linear gradient from 5 to $40 \%$ solvent A to B (Solvent A: $5 \%$ acetonitrile/0.1\% formic acid, Solvent B: $80 \%$ acetonitrile $/ 0.1 \%$ formic acid) over $60 \mathrm{~min}$ at a flow rate of $30 \mathrm{nl} / \mathrm{min}$.

Nano-liquid chromatography-electrospray ionizationtandem mass spectrometry (LC-ESI-MS/MS) analysis. The digests were analyzed using an Eksigent nanoLC $C^{\mathrm{TM}}-1 \mathrm{D}-$ plus (SCIEX, Framingham, MA, USA) coupled to a LTQ $\mathrm{XL}^{\mathrm{TM}}$ Linear Ion Trap mass spectrometer (Thermo Fisher Scientific, Inc.) as follows: The digests were loaded onto an online dual trap set up (Eksigent Chrom XP nanoLC trap-column C18-CL-3 $\mu \mathrm{m} 120 \AA$, $350 \mu \mathrm{m}$ x0.5 mm) at a flow rate of $1.5 \mu \mathrm{l} / \mathrm{min}$ using channel $1 \mathrm{~A}$ solution [98\% water, $2 \%$ acetonitrile (ACN), $0.5 \%$ formic acid (FA)]. Separation was achieved on an Eksigent Chrom XP nano-LC C18-reverse phase column (3C18-CL-3 $\mu \mathrm{m} 120 \AA$, $0.075 \times 150 \mathrm{~mm})$ using channel 2 mobile phases (solvent 2A: $5 \%$ ACN/ $0.1 \%$ FA; solvent 2B: $80 \%$ ACN/0.1\% FA, on a linear gradient of $5-45 \%$ 2B over $60 \mathrm{~min}$ at a flow rate of $300 \mathrm{nl} / \mathrm{min})$. The MS system was set to perform one full scan $(400-1,700 \mathrm{~m} / \mathrm{z}$ range) followed by MS/MS scans of the 10 most abundant parent-ions (ESI voltage, $3 \mathrm{kV}$; isolation width, $3.0 \mathrm{~m} / \mathrm{z} ; 35$ normalized collision energy). The dynamic exclusion was set to collect each parent-ion twice and then excluded for $120 \mathrm{sec}$.

Data analysis. The resulting MS/MS spectra (350-5,000 Da, monoisotopic) were searched against a Uniprot protein database (http://www.uniprot.org/) downloaded on April 4, 2013 comprising Homo sapiens, Bos Taurus and porcine trypsin using a SEQUEST ${ }^{\circledR}$ algorithm in Proteome Discoverer 1.4 software (Thermo Fisher Scientific, Inc.). The parameters for database search were: i) 2.0 and $1.0 \mathrm{Da}$ for peptide and fragment mass tolerance, respectively; ii) full digest using trypsin after $\mathrm{K} / \mathrm{R}$ (cleaving $\mathrm{C}$-terminal of $\mathrm{K}$ and $\mathrm{R}$ amino acid residues) with up to two missed cleavages allowed; and iii) methionine oxidation as a fixed modification, and cysteine carbamidomethylation and deamidation of asparagine and 
A

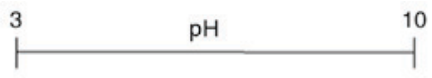

SDS-PAGE

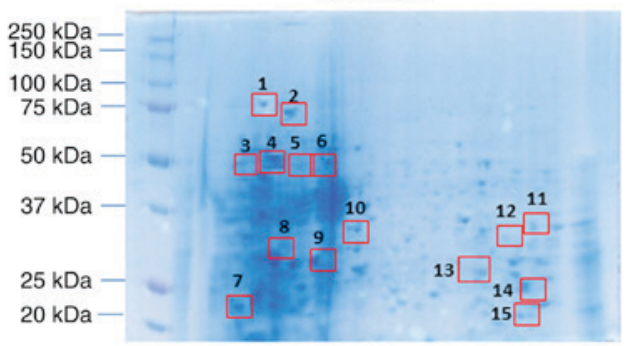

B

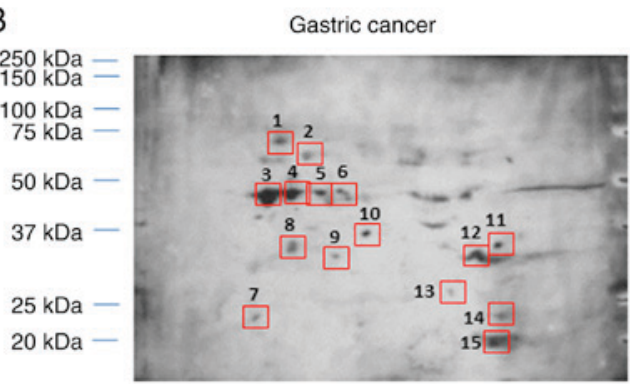

C

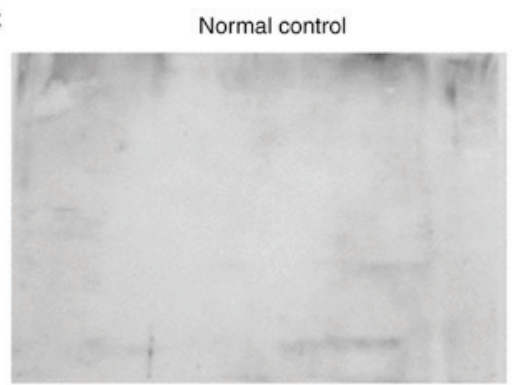

Figure 1. Screening of tumor-associated antigens. (A) Proteins from AGS cell lysates were separated by two-dimensional gel electrophoresis and visualized by Coomassie blue staining. (B) Proteins from AGS cell lysates were transferred to a NC membrane, which was then incubated with diluted sera from patients with gastric cancer. (C) NC membrane cultivated with sera from normal controls. NC, nitrocellulose.

glutamine as variable modifications. At least 2 peptides were used for assignment of proteins and search results were filtered for a false discovery rate of $1 \%$, employing a decoy search strategy utilizing a reverse database.

Recombinant proteins and antibodies. The recombinant 14-3-3 $\zeta$ protein were provided by our laboratory (Department of Biology Sciences, UTEP; El Paso, TX, USA) (20). Polyclonal

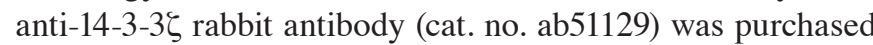
from Abcam, Inc. (Cambridge, MA, USA). Horseradish peroxidase (HRP)-conjugated goat anti-rabbit IgG (cat. no. sc-2004) was from Santa Cruz Biotechnology, Inc. (Dallas, TX, USA), and HRP-conjugated goat anti-human IgG (cat. no. 31410) from Invitrogen (Thermo Fisher Scientific, Inc.). The recombinant proteins were for ELISA and antibodies for western blotting analysis.

ELISA. After diluting the 14-3-35 protein in PBS to a final concentration of $0.5 \mu \mathrm{g} / \mathrm{ml}$ to coat polystyrene 96 -well microtiter plates (Thermo Fisher Scientific, Inc.), the plates were blocked with gelatin post-coating solution at room temperature for $2 \mathrm{~h}$. The antigen-coated wells were incubated with human

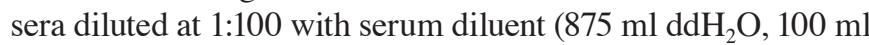
gelatin at $10 \mathrm{mg} / \mathrm{ml}, 20 \mathrm{ml} 0.5 \mathrm{M}$ phosphate buffer, $8.2 \mathrm{~g} \mathrm{NaCl}$, $0.1 \mathrm{~g}$ Thimerosal, $5 \mathrm{~g}$ bovine gamma globulin, $1 \mathrm{~g}$ bovine serum albumin and $5 \mathrm{ml} \mathrm{10 \% -Tween-20)} \mathrm{at} \mathrm{room} \mathrm{temperature} \mathrm{for}$ $2 \mathrm{~h}$. The final reactivity was detected using goat anti-human IgG-HRP and the substrate 2,2'-azino-bis-(3-ethylbenzo-thiazoline-6-sulfonic acid) (Invitrogen; Thermo Fisher Scientific, Inc.) (17). Data were analyzed by measuring the average optical density (OD) value at a wavelength of $405 \mathrm{~nm}$. The cut-off value, which indicated a positive reaction, was the mean OD of 85 normal human sera (NHS) +3 standard deviations.
Statistical analysis. Statistical analysis was conducted using SPSS software version 21.0 (IBM Corp., Armonk, NY, USA). Data were assessed by $\chi^{2}$ test and ELISA data are presented as the mean \pm 3 standard deviations. $\mathrm{P}<0.01$ was considered to indicate a statistically significant difference.

\section{Results}

Identification of immunoreactive proteins in GC cells by $L C-M S / M S$. Proteins from AGS cell lysates were isolated with 2-DE and visualized by Coomassie blue staining (Fig. 1A). To determine autoantibodies against antigens from AGS, proteins were isolated by 2-DE, transferred onto $\mathrm{NC}$ membranes and then probed with sera from 10 patients with GC or 10 healthy controls. These sera were randomly chosen in both groups. Each NC membrane was incubated with mixed sera samples as the primary antibody, followed by an HRP-conjugated goat anti-human $\mathrm{IgG}$ as a secondary antibody. The reactivity of patients' sera with GC resulted in 15 spots (Fig. 1B), whereas no reactive protein spots were observed in the normal control samples (Fig. 1C). Therefore, the sera were considered to have non-specific reactivity. In the subsequent study, 15 immunoreactive protein spots were excised from the SDS-PAGE gels, digested with trypsin and further analyzed by LC-MS/MS. The resulting MS/MS spectra were searched with a Uniprot protein database, which is a comprehensive database for human protein sequences. As demonstrated in Table I, 14 of the 15 protein spots were identified by LC-MS/MS, with the exception of one uncharacteristic protein.

Prevalence and autoantibody titers against 14-3-3\} in GC. Sera from patients with GC and normal controls were tested for the response of autoantibodies to $14-3-3 \zeta$. The sera that 
Table I. Summary of identified protein spots by mass spectrometry.

\begin{tabular}{|c|c|c|c|c|c|}
\hline $\begin{array}{l}\text { Spot } \\
\text { no. }\end{array}$ & $\begin{array}{l}\text { Accession } \\
\text { no. }\end{array}$ & $\begin{array}{l}\text { Identified } \\
\text { protein }\end{array}$ & $\begin{array}{l}\text { Molecular } \\
\text { mass (kDa) }\end{array}$ & $\begin{array}{c}\text { Protein } \\
\text { abundance }\end{array}$ & Protein functions \\
\hline 1 & P11021 & GRP78 & 78 & 56 & $\begin{array}{l}\text { Interacts with many endoplasmic reticulum protein } \\
\text { and monitors transport through the cell }\end{array}$ \\
\hline 2 & B1AHM1 & $\begin{array}{l}\text { DEAD (Asp-Glu- } \\
\text { Ala-Asp) box } \\
\text { polypeptide } 17\end{array}$ & 72.5 & 35 & $\begin{array}{l}\text { Implicated in a number of cellular processes } \\
\text { involving alteration of RNA secondary structure }\end{array}$ \\
\hline 3 & Q53G71 & Calreticulin variant & 46.9 & 30 & $\begin{array}{l}\text { Acts as a major } \mathrm{Ca}^{2+} \text {-binding protein in the lumen } \\
\text { of the endoplasmic reticulum }\end{array}$ \\
\hline 4 & Q53G71 & Calreticulin variant & 46.9 & 17 & $\begin{array}{l}\text { Acts as a major } \mathrm{Ca}^{2+} \text {-binding protein in the lumen } \\
\text { of the endoplasmic reticulum }\end{array}$ \\
\hline 5 & Q53G71 & Calreticulin variant & 46.9 & 21 & $\begin{array}{l}\text { Acts as a major } \mathrm{Ca}^{2+} \text {-binding protein in the lumen } \\
\text { of the endoplasmic reticulum }\end{array}$ \\
\hline 6 & Q53G71 & Calreticulin variant & 46.9 & 42 & $\begin{array}{l}\text { Acts as a major } \mathrm{Ca}^{2+} \text {-binding protein in the lumen } \\
\text { of the endoplasmic reticulum }\end{array}$ \\
\hline 7 & P62820 & $\begin{array}{l}\text { Ras-related } \\
\text { protein Rab-1A }\end{array}$ & 22.7 & 61 & $\begin{array}{l}\text { Controls vesicle traffic from the endoplasmic } \\
\text { reticulum to the Golgi apparatus }\end{array}$ \\
\hline 8 & B4E3C4 & $\begin{array}{l}\text { Uncharacterized } \\
\text { protein }\end{array}$ & 33.8 & 5 & - \\
\hline 9 & E7EUT4 & $\begin{array}{l}\text { Glyceraldehyde-3- } \\
\text { phosphate } \\
\text { dehydrogenase }\end{array}$ & 31.5 & 59 & Serves a role in glycolysis and nuclear functions \\
\hline 10 & B4DVQ0 & Actin & 37.3 & 14 & Involved in various types of cell motility \\
\hline 11 & P22626 & hnRNP A2/B1 & 37.4 & 17 & Serves an important role in proliferation \\
\hline 12 & Q1WWK5 & SEPT9 protein & 36.5 & 9 & Is overexpressed in diverse human tumors \\
\hline 13 & P63104 & $14-3-3$ protein zeta & 27.7 & 45 & $\begin{array}{l}\text { Mediates signal transduction by binding to } \\
\text { phosphoserine-containing proteins }\end{array}$ \\
\hline 14 & Q06830 & Peroxiredoxin-1 & 23 & 55 & Serves a role in cancer development or progression \\
\hline 15 & P30086 & PEBP & 21 & 2 & Interacts with MAP2K1, c-Raf and MAPK1 \\
\hline
\end{tabular}

GRP78, glucose-regulated protein 78; DDX3X, DEAD-box helicase 3 X-linked; Rab1a, RAB1A member of RAS oncogene family; hnRNP A2/B1, heterogeneous nuclear ribonucleoprotein A2/B1; SEPT9, septin 9; PEBP, phosphatidylethanolamine-binding protein; MAP2K1, mitogen-activated protein kinase kinase 1; MAPK1, mitogen-activated protein kinase 1; c-Raf, proto-oncogene c-RAF.

were detected included 85 from patients with GC, and 85 from normal human individuals. Table II revealed that autoantibody frequency to $14-3-3 \zeta$ was $17.6 \%(15 / 85)$ in GC sera, which was significantly higher than that in NHS $(2.4 \% ; 2 / 85 ; \mathrm{P}<0.01)$. In addition, as presented in Fig. 2, autoantibody titers against $14-3-3 \zeta$ in GC sera were higher than in NHS $(\mathrm{P}<0.01)$. These ELISA results were further confirmed by western blot analysis (Fig. 3), where a positive reaction to 14-3-3 $\zeta$ was observed in representative GC sera compared with normal sera.

\section{Discussion}

The recognition of TAAs that evoke an antibody response may be utilized for the early diagnosis of cancer, in monitoring prognosis and as immunotherapy targets $(21,22)$. With advancement in protein isolation and identification methods, proteomics-based technologies have acquired increased popularity for the detection and recognition of TAAs and associated autoantibodies. Thus, 2-D/MS remains a key technique in
Table II. Frequency of autoantibodies against $14-3-3 \zeta$ in human sera, as determined by ELISA.

\begin{tabular}{lcc}
\hline $\begin{array}{l}\text { Type of } \\
\text { sera }\end{array}$ & $\begin{array}{c}\text { No. } \\
\text { tested }\end{array}$ & $\begin{array}{c}\text { Autoantibody to } \\
14-3-3 \zeta(\%)\end{array}$ \\
\hline GC & 85 & $15(17.6)^{\mathrm{a}}$ \\
NHS & 85 & $2(2.4)$ \\
\hline
\end{tabular}

Cut-off value: Mean +3 standard deviations of NHS; ${ }^{a} \mathrm{P}<0.01$ vs. NHS. GC, gastric cancer; NHS, normal.

proteomics for global protein profiling and serves a complementary role to LC-MS-based analysis (23). In addition, it enables experiments to be performed with autoantibodies, and therefore improves screening of antigenicity associated with abnormal post-translational alterations of cancer cell proteins. 


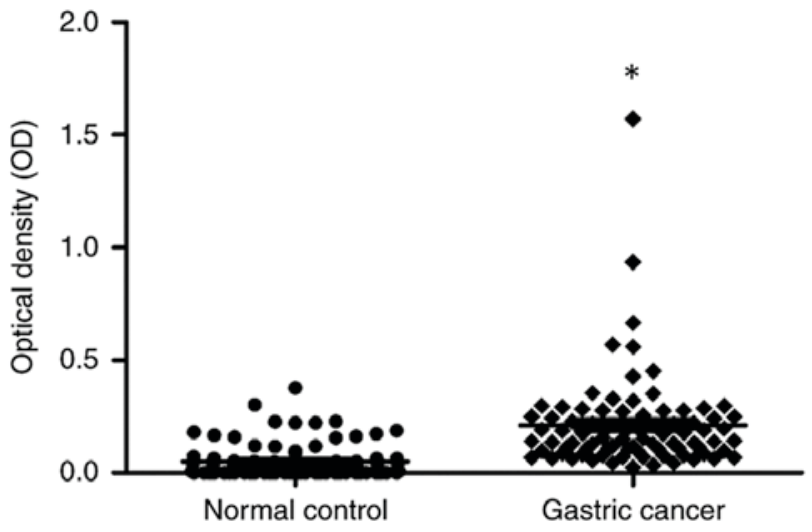

Figure 2. Autoantibody titers to $14-3-3 \zeta$ in sera of patients with GC or normal controls. The range of antibody titers to $14-3-3 \zeta$ were expressed as OD obtained via ELISA. Titers of autoantibody to $14-3-3 \zeta$ were greater in GC sera compared with in normal control sera. ${ }^{*} \mathrm{P}<0.01$. GC, gastric cancer; OD, optical density.

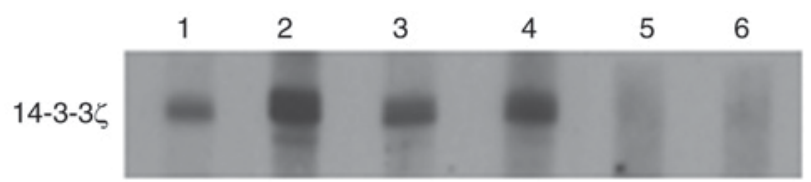

Figure 3. Reactivity of GC or normal control sera to $14-3-3 \xi$, as determined by western blotting. The polyclonal anti-14-3-3 $\zeta$ antibody served as a positive control (lane 1). Sera from three representative GC patients, which were positive by ELISA, also had strong reactivity with 14-3-3 $\zeta$ recombinant protein by western blotting (lane 2, 3 and 4). Randomly selected normal control sera that had negative reactivity (lane 5 and 6). GC, gastric cancer.

Proteomics techniques have been adopted to explore protein expression in various human cancers. The most widely used technique for large-scale protein expression detection is 2-DE combined with MS, which may be an optimal method in the pursuit of reliable immunodiagnostic biomarkers. With this proteomic technique, autoantibodies against annexin-II (24), annexin-I, protein gene product 9.5 (25), peroxiredoxin-I (26), calreticulin (27), peroxiredoxin-VI (28) and RS/DJ-1 (29), have been identified in the sera of patients with pancreatic, lung, esophageal squamous cell and breast cancers.

In the present study, an immunoproteomics-based approach was used to identify biomarkers associated with the humoral immune responses in patients with GC. This approach incorporated SDS-PAGE, 2-DE and western blotting to detect autoantibodies in sera from patients with $\mathrm{GC}$, which reacted to proteins separated by 2-DE and were confirmed by MS. In total, 11 available proteins were identified. One of them, glucose-regulated protein 78 (GRP78), has been regarded as a diagnostic biomarker for GC (30). Two other proteins, actin and GAPDH, are housekeeping proteins. Therefore, the 8 remaining tumor-associated proteins may be considered candidate antigens.

The molecular functions of the identified proteins have been documented in the literature, and the majority of these proteins are associated with various cellular functions, including cell differentiation, proliferation, apoptosis and signaling transduction. To further investigate the association of these identified proteins with cancer, literature searches were conducted using PubMed (http://www.ncbi.nlm.nih. gov/pubmed/). GRP78 is a molecular chaperone in the endoplasmic reticulum (ER), which may be a candidate biomarker in GC (30). DEAD-box helicase $3 \mathrm{X}$-linked (DDX3X) is a hepatitis $\mathrm{C}$ virus core protein-associated cellular factor that belongs to the DEAD box RNA helicase family (31-33). Whole-exome analyses have revealed that mutated DDX3X serves an essential role in oncogenesis (34). Calreticulin is also an ER chaperone, which serves a role as a stress protein. Overexpression of calreticulin occurs in numerous malignancies, including in cancers of the prostate, breast, bladder, liver and lung (35-38). Rab-1A, which is a Ras-associated protein, may be of pathological significance in dealing with glucocorticoid-induced osteoporosis (39). GAPDH and actin have various functions in cells, in particular, they serve a vital role in the control of gene expression. Heterogeneous nuclear ribonucleoprotein A2/B1 (hnRNP A2/B1) is a member of the hnRNP A/B family that may be considered a prognostic marker of hepatocellular carcinoma (40). Septin 9, which is a cytoskeletal component, has been recognized as a promising oncogene in breast tumorigenesis (41). 14-3-3 $\zeta$ is a member of a family of seven highly conserved proteins that is considered a novel predictive biomarker of tamoxifen therapeutic resistance in breast cancer $(42,43)$. Peroxiredoxin- 1 is a member of the peroxiredoxin family of antioxidant enzymes and may be a potential biomarker for screening patients with hepatocellular carcinoma (44). Phosphatidylethanolamine-binding protein is regarded as a signal transduction mediator and a suppression of metastasis in cancer, and is often downregulated in various human malignancies (45), primarily in highly metastatic cancers (46-50). However, the present study focused on the $14-3-3 \zeta$ protein to identify whether this antigen may be considered a tumor biomarker in the immunodiagnosis of GC. As these identified proteins are associated with cancer, future work to evaluate which of these may be attractive TAAs in GC is required.

The 14-3-3 proteins are highly conserved regulatory molecules that are universally expressed in all eukaryotic organisms (51). In humans, seven isoforms of 14-3-3 ( $\beta, \varepsilon, \eta$, $\gamma, \tau, \zeta$ and $\sigma$ ) have been verified (52). Although 14-3-3 proteins are short of endogenous enzymatic activity, they function by forming homo- or hetero-dimers and binding to phosphorylated-serine/threonine motifs on their target proteins (53). By modulation of their binding cooperators, 14-3-3 proteins have been implicated to regulate a mass of cellular processes, including mitogenesis, apoptosis, cell cycle progression, stress signaling, metabolism, cytoskeletal integrity and transcription $(54,55)$. Numerous studies have reported that members of the 14-3-3 family, particularly 14-3-3 $\zeta$, serve a pro-oncogenic role in various tumor types, and overexpression of $14-3-3 \zeta$ is primarily associated with poor survival of patients with cancer $(56,57) .14-3-3 \zeta$ has been recognized as a clinically relevant prognostic marker for lung cancer, breast cancer, and head and neck cancer (58-60). The present study identified $14-3-3 \zeta$ as a candidate biomarker for GC and determined autoantibodies against 14-3-3 $\zeta$ by ELISA and western blot analysis. It was demonstrated that serum autoantibody prevalence to $14-3-3 \zeta$ was significantly stronger in patients with GC $(17.6 \%)$ than in normal individuals $(2.4 \%)$. Intensive studies are required to assess the sensitivity and specificity of 
autoantibodies against $14-3-3 \xi$ in a greater number of samples, and to explore the underlying molecular mechanism of autoantibody response to $14-3-3 \zeta$ in the progression of GC.

14-3-3 proteins are generally cytosolic but also bind to several nuclear proteins; therefore, it is hypothesized that they may serve as a cytoplasmic anchor and block nuclear import of target proteins (61). Several proteins whose nuclear trafficking is regulated by 14-3-3 include a bipartite nuclear localization signal (NLS). 14-3-3 binding masks the NLS and displaces the import complex, which leads to the cytoplasmic localization of target proteins (61). 14-3-3 proteins do not have any catalytic activity; however, they exert their effect by modulating subcellular localization or catalytic activity of target proteins and by regulating formation of protein complexes (62). 14-3-3 proteins interact with several proteins that potentially mediate various cellular processes $(63,64)$. Therefore, $14-3-3 \zeta$ may bind several proteins and potentially mediate the protein complex involved in numerous biological functions and tumor progression.

In conclusion, the present study detected autoantibodies against $14-3-3 \zeta$ in sera from patients with GC. 14-3-3 $\zeta$ may be attractive not only as a serological tumor biomarker, but also to guide efficient immunological surveillance. With regards to the detection of novel autoantibodies, including 14-3-3\}, the proteomics approach employed in the present study may be considered a promising method to identify potential proteins that have clinical utility in malignancy.

\section{Acknowledgements}

The present study was supported by grants from the Project for Tackling Key Problems in Science and Technology of Henan province (grant no. 162102410044), the Major project of Science and Technology in Henan province (grant no. 161100311400), the Zhongyuan Scholar Program of Henan Province (grant no. 162101510006) and the Key Scientific Research Project of Henan Province (grant no. 16A330007).

\section{References}

1. Bertuccio P, Chatenoud L, Levi F, Praud D, Ferlay J, Negri E, Malvezzi M and La Vecchia C: Recent patterns in gastric cancer: A global overview. Int J Cancer 125: 666-673, 2009.

2. Peleteiro B, Bastos A, Ferro A and Lunet N: Prevalence of helicobacter pylori infection worldwide: A systematic review of studies with national coverage. Dig Dis Sci 59: 1698-1709, 2014.

3. Kamangar F, Dores GM and Anderson WF: Patterns of cancer incidence, mortality, and prevalence across five continents: Defining priorities to reduce cancer disparities in different geographic regions of the world. J Clin Oncol 24: 2137-2150, 2006.

4. Hiripi E, Jansen L, Gondos A, Emrich K, Holleczek B, Katalinic A, Luttmann S, Nennecke A and Brenner H; Gekid Cancer Survival Working Group: Survival of stomach and esophagus cancer patients in Germany in the early 21st century. Acta Oncol 51: 906-914, 2012.

5. Hundahl SA, Phillips JL and Menck HR: The National Cancer Data Base Report on poor survival of U.S. gastric carcinoma patients treated with gastrectomy: Fifth Edition American Joint Committee on Cancer staging, proximal disease, and the 'different disease' hypothesis. Cancer 88: 921-932, 2000.

6. Ushijima $\mathrm{T}$ and Sasako M: Focus on gastric cancer. Cancer Cell 5: 121-125, 2004

7. Srinivas PR, Kramer BS and Srivastava S: Trends in biomarker research for cancer detection. Lancet Oncol 2: 698-704, 2001.

8. Tan HT, Low J, Lim SG and Chung MC: Serum autoantibodies as biomarkers for early cancer detection. FEBS J 276: 6880-6904, 2009.
9. Anderson KS and LaBaer J: The sentinel within: Exploiting the immune system for cancer biomarkers. J Proteome Res 4: 1123-1133, 2005.

10. Caron M, Choquet-Kastylevsky G and Joubert-Caron R: Cancer immunomics using autoantibody signatures for biomarker discovery. Mol Cell Proteomics 6: 1115-1122, 2007.

11. Casiano CA, Mediavilla-Varela M and Tan EM: Tumor-associated antigen arrays for the serological diagnosis of cancer. Mol Cell Proteomics 5: 1745-1759, 2006.

12. Fernandez Madrid F: Autoantibodies in breast cancer sera: Candidate biomarkers and reporters of tumorigenesis. Cancer Lett 230: 187-198, 2005.

13. Tan EM: Autoantibodies as reporters identifying aberrant cellular mechanisms in tumorigenesis. J Clin Invest 108: 1411-1415, 2001.

14. Davis MA and Hanash S: High-throughput genomic technology in research and clinical management of breast cancer. Plasma-based proteomics in early detection and therapy. Breast Cancer Res 8: 217, 2006.

15. Looi KS, Nakayasu ES, Diaz RA, Tan EM, Almeida IC and Zhang JY: Using proteomic approach to identify tumor-associated antigens as markers in hepatocellular carcinoma. J Proteome Res 7: 4004-4012, 2008.

16. Zhang J, Wang K, Zhang J, Liu SS, Dai L and Zhang JY: Using proteomic approach to identify tumor-associated proteins as biomarkers in human esophageal squamous cell carcinoma. J Proteome Res 10: 2863-2872, 2011.

17. Peng B, Huang X, Nakayasu ES, Petersen JR, Qiu S, Almeida IC and Zhang JY: Using immunoproteomics to identify alpha-enolase as an autoantigen in liver fibrosis. J Proteome Res 12: 1789-1796, 2013.

18. Yegin EG and Duman DG: Staging of esophageal and gastric cancer in 2014. Minerva Med 105: 391-411, 2014.

19. Jung E, Heller M, Sanchez JC and Hochstrasser DF: Proteomics meets cell biology: The establishment of subcellular proteomes. Electrophoresis 21: 3369-3377, 2000.

20. Dai L, Tsay JC, Li J, Yie TA, Munger JS, Pass H, Rom WN, Zhang Y, Tan EM and Zhang JY: Autoantibodies against tumor-associated antigens in the early detection of lung cancer. Lung Cancer 99: 172-179, 2016.

21. Fernandez-Madrid F, Tang N, Alansari H, Granda JL, Tait L, Amirikia KC, Moroianu M, Wang $X$ and Karvonen RL: Autoantibodies to Annexin XI-A and other autoantigens in the diagnosis of breast cancer. Cancer Res 64: 5089-5096, 2004.

22. Kim JH, Herlyn D, Wong KK, Park DC, Schorge JO, Lu KH, Skates SJ, Cramer DW, Berkowitz RS and Mok SC: Identification of epithelial cell adhesion molecule autoantibody in patients with ovarian cancer. Clin Cancer Res 9: 4782-4791, 2003.

23. Timms JF and Cramer R: Difference gel electrophoresis. Proteomics 8: 4886-4897, 2008.

24. Brichory FM, Misek DE, Yim AM, Krause MC, Giordano TJ, Beer DG and Hanash SM: An immune response manifested by the common occurrence of annexins I and II autoantibodies and high circulating levels of IL-6 in lung cancer. Proc Natl Acad Sci USA 98: 9824-9829, 2001.

25. Brichory F, Beer D, Le Naour F, Giordano T and Hanash S: Proteomics-based identification of protein gene product 9.5 as a tumor antigen that induces a humoral immune response in lung cancer. Cancer Res 61: 7908-7912, 2001.

26. Chang JW, Lee SH, Jeong JY, Chae HZ, Kim YC, Park ZY and Yoo YJ: Peroxiredoxin-I is an autoimmunogenic tumor antigen in non-small cell lung cancer. FEBS Lett 579: 2873-2877, 2005.

27. Hong SH, Misek DE, Wang H, Puravs E, Giordano TJ, Greenson JK, Brenner DE, Simeone DM, Logsdon CD and Hanash SM: An autoantibody-mediated immune response to calreticulin isoforms in pancreatic cancer. Cancer Res 64: 5504-5510, 2004.

28. Fujita Y, Nakanishi T, Hiramatsu M, Mabuchi H, Miyamoto Y, Miyamoto A, Shimizu A and Tanigawa N: Proteomics-based approach identifying autoantibody against peroxiredoxin VI as a novel serum marker in esophageal squamous cell carcinoma. Clin Cancer Res 12: 6415-6420, 2006.

29. Le Naour F, Misek DE, Krause MC, Deneux L, Giordano TJ, Scholl S and Hanash SM: Proteomics-based identification of RS/DJ-1 as a novel circulating tumor antigen in breast cancer. Clin Cancer Res 7: 3328-3335, 2001.

30. Wu JY, Cheng CC, Wang JY, Wu DC, Hsieh JS, Lee SC and Wang WM: Discovery of tumor markers for gastric cancer by proteomics. PLoS One 9: e84158, 2014.

31. You LR, Chen CM, Yeh TS, Tsai TY, Mai RT, Lin CH and Lee YH: Hepatitis C virus core protein interacts with cellular putative RNA helicase. J Virol 73: 2841-2853, 1999. 
32. Owsianka AM and Patel AH: Hepatitis $\mathrm{C}$ virus core protein interacts with a human DEAD box protein DDX3. Virology 257: 330-340, 1999.

33. Mamiya $\mathrm{N}$ and Worman $\mathrm{HJ}$ : Hepatitis $\mathrm{C}$ virus core protein binds to a DEAD box RNA helicase. J Biol Chem 274: 15751-15756, 1999.

34. Pugh TJ, Weeraratne SD, Archer TC, Pomeranz Krummel DA, Auclair D, Bochicchio J, Carneiro MO, Carter SL, Cibulskis K, Erlich RL, et al: Medulloblastoma exome sequencing uncovers subtype-specific somatic mutations. Nature 488: 106-110, 2012.

35. Alur M, Nguyen MM, Eggener SE, Jiang F, Dadras SS, Stern J, Kimm S, Roehl K, Kozlowski J, Pins M, et al: Suppressive roles of calreticulin in prostate cancer growth and metastasis. Am J Pathol 175: 882-890, 2009

36. Chignard N, Shang S, Wang H, Marrero J, Bréchot C, Hanash S and Beretta L: Cleavage of endoplasmic reticulum proteins in hepatocellular carcinoma: Detection of generated fragments in patient sera. Gastroenterology 130: 2010-2022, 2006.

37. Gromov P, Gromova I, Bunkenborg J, Cabezon T, Moreira JM, Timmermans-Wielenga V, Roepstorff P, Rank F and Celis JE: Up-regulated proteins in the fluid bathing the tumour cell microenvironment as potential serological markers for early detection of cancer of the breast. Mol Oncol 4: 65-89, 2010.

38. Iwaki H, Kageyama S, Isono T, Wakabayashi Y, Okada Y, Yoshimura K, Terai A, Arai Y, Iwamura H, Kawakita M and Yoshiki T: Diagnostic potential in bladder cancer of a panel of tumor markers (calreticulin, gamma-synuclein, and catechol-o-methyltransferase) identified by proteomic analysis. Cancer Sci 95: 955-961, 2004.

39. Hong D, Chen HX, Yu HQ, Wang C, Deng HT, Lian QQ and Ge RS: Quantitative proteomic analysis of dexamethasone-induced effects on osteoblast differentiation, proliferation, and apoptosis in MC3T3-E1 cells using SILAC. Osteoporos Int 22: 2175-2186, 2011.

40. Mizuno H, Honda M, Shirasaki T, Yamashita T, Yamashita T, Mizukoshi E and Kaneko S: Heterogeneous nuclear ribonucleoprotein A2/B1 in association with hTERT is a potential biomarker for hepatocellular carcinoma. Liver Int 32: 1146-1155, 2012.

41. Montagna C, Lyu MS, Hunter K, Lukes L, Lowther W, Reppert T, Hissong B, Weaver Z and Ried T: The Septin 9 (MSF) gene is amplified and overexpressed in mouse mammary gland adenocarcinomas and human breast cancer cell lines. Cancer Res 63: 2179-2187, 2003

42. Bergamaschi A, Christensen BL and Katzenellenbogen BS Reversal of endocrine resistance in breast cancer: Interrelationships among 14-3-3 6 , FOXM1, and a gene signature associated with mitosis. Breast Cancer Res 13: R70, 2011.

43. Frasor J, Chang EC, Komm B, Lin CY, Vega VB, Liu ET, Miller LD, Smeds J, Bergh J and Katzenellenbogen BS: Gene expression preferentially regulated by tamoxifen in breast cancer cells and correlations with clinical outcome. Cancer Res 66: 7334-7340, 2006.

44. Sun QK, Zhu JY, Wang W, Lv Y, Zhou HC, Yu JH, Xu GL, Ma JL, Zhong W and Jia WD: Diagnostic and prognostic significance of peroxiredoxin 1 expression in human hepatocellular carcinoma. Med Oncol 31: 786, 2014.

45. Granovsky AE and Rosner MR: Raf kinase inhibitory protein: A signal transduction modulator and metastasis suppressor. Cell Res 18: 452-457, 2008.

46. AkaishiJ,OndaM,AsakaS,OkamotoJ,MiyamotoS,NagahamaM, Ito K, Kawanami O and Shimizu K: Growth-suppressive function of phosphatidylethanolamine-binding protein in anaplastic thyroid cancer. Anticancer Res 26: 4437-4442, 2006.
47. Houben R, Michel B, Vetter-Kauczok CS, Pföhler C, Laetsch B, Wolter MD, Leonard JH, Trefzer U, Ugurel S, Schrama D and Becker JC: Absence of classical MAP kinase pathway signalling in Merkel cell carcinoma. J Invest Dermatol 126: 1135-1142, 2006.

48. Chen Y, Ouyang GL, Yi H, Li MY, Zhang PF, Li C, Li JL, Liu YF, Chen ZC and Xiao ZQ: Identification of RKIP as an invasion suppressor protein in nasopharyngeal carcinoma by proteomic analysis. J Proteome Res 7: 5254-5262, 2008.

49. Fu Z, Smith PC, Zhang L, Rubin MA, Dunn RL, Yao Z and Keller ET: Effects of raf kinase inhibitor protein expression on suppression of prostate cancer metastasis. J Natl Cancer Inst 95: 878-889, 2003.

50. Chatterjee D, Bai Y, Wang Z, Beach S, Mott S, Roy R, Braastad C, Sun Y, Mukhopadhyay A, Aggarwal BB, et al: RKIP sensitizes prostate and breast cancer cells to drug-induced apoptosis. J Biol Chem 279: 17515-17523, 2004

51. Aitken A: 14-3-3 proteins on the MAP. Trends Biochem Sci 20: 95-97, 1995.

52. Aitken A: 14-3-3 proteins: A historic overview. Semin Cancer Biol 16: 162-172, 2006.

53. Muslin AJ, Tanner JW, Allen PM and Shaw AS: Interaction of 14-3-3 with signaling proteins is mediated by the recognition of phosphoserine. Cell 84: 889-897, 1996.

54. van Hemert MJ, Steensma HY and van Heusden GP: 14-3-3 proteins: key regulators of cell division, signalling and apoptosis. Bioessays 23: 936-946, 2001.

55. Tzivion G, Gupta VS, Kaplun L and Balan V: 14-3-3 proteins as potential oncogenes. Semin Cancer Biol 16: 203-213, 2006.

56. Zhao J, Meyerkord CL, Du Y, Khuri FR and Fu H: 14-3-3 proteins as potential therapeutic targets. Semin Cell Dev Biol 22: 705-712, 2011.

57. Neal CL and Yu D: 14-3-3६ as a prognostic marker and therapeutic target for cancer. Expert Opin Ther Targets 14: 1343-1354, 2010.

58. Lu J, Guo H, Treekitkarnmongkol W, Li P, Zhang J, Shi B, Ling C, Zhou X, Chen T, Chiao PJ, et al: 14-3-3zeta Cooperates with ErbB2 to promote ductal carcinoma in situ progression to invasive breast cancer by inducing epithelial-mesenchymal transition. Cancer cell 16: 195-207, 2009 .

59. MattaA,DeSouzaLV,ShuklaNK, GuptaSD, RalhanR and Siu KW: Prognostic significance of head-and-neck cancer biomarkers previously discovered and identified using iTRAQ-labeling and multidimensional liquid chromatography-tandem mass spectrometry. J Proteome Res 7: 2078-2087, 2008.

60. Fan T, Li R, Todd NW, Qiu Q, Fang HB, Wang H, Shen J, Zhao RY, Caraway NP, Katz RL, et al: Up-regulation of 14-3-3zeta in lung cancer and its implication as prognostic and therapeutic target. Cancer Res 67: 7901-7906, 2007.

61. Muslin AJ and Xing H: 14-3-3 proteins: Regulation of subcellular localization by molecular interference. Cell Signal 12: 703-709, 2000.

62. Tzivion G and Avruch J: 14-3-3 proteins: Active cofactors in cellular regulation by serine/threonine phosphorylation. J Biol Chem 277: 3061-3064, 2002.

63. Benzinger A, Muster N, Koch HB, Yates JR III and Hermeking H: Targeted proteomic analysis of 14-3-3 sigma, a p53 effector commonly silenced in cancer. Mol Cell Proteomics 4: 785-795, 2005.

64. Jin J, Smith FD, Stark C, Wells CD, Fawcett JP, Kulkarni S, Metalnikov P, O'Donnell P, Taylor P, Taylor L, et al: Proteomic, functional, and domain-based analysis of in vivo 14-3-3 binding proteins involved in cytoskeletal regulation and cellular organization. Curr Biol 14: 1436-1450, 2004. 